\title{
Bone Augmentation With Occlusive Barriers and Cortical Particulate Allograft in Transverse Maxillary Defects: A Pilot Study
}

\author{
Aumento Óseo con Barreras Oclusivas y Aloinjerto Cortical \\ Particulado en Defectos Maxilares Transversales: Un Estudio Piloto
}

\author{
Víctor Beltrán",***;ilfried Engelke**; Ramón Fuentes*; Oscar Decco***; \\ Ruth Prieto $^{* * * * *}$; Mario Wilckens ${ }^{* * * * * *}$ \& Eduardo Borie ${ }^{*, * * * * * * *}$
}

BELTRÁN, V.; ENGELKE, W.; FUENTES, R.; DECCO, O.; PRIETO, R.; WILCKENS, M. \& BORIE, E. Bone augmentation with occlusive barriers and cortical particulate allograft in transverse maxillary defects: a pilot study. Int. J. Morphol., 32(1):364-368, 2014.

SUMMARY: The centripetal resorption of maxilla is a continuous process after tooth loss. For treatment of deficient bone sites, autologous bone grafts may be used, as an alternative, biomaterials can be applied which do not require intra or extraoral donor sites. The present report describes the use of occlusive barriers and cortical particulate allograft in transverse maxillary defects. This surgical approach was performed in five patients (4 females and 1 male, aged 20 to 37 years). Clinical results show that sufficient hard tissue was formed to allow implant born rehabilitation in the former insufficient bone sites. Histological evaluation revealed small amounts of newly formed bone with a predominance of collagen fibrous tissue and mature bone with very little cellular elements. Depending on the original site situation, the minimally invasive approach with occlusive barrier and cortical particulate allograft may be applied. We observed a mean of 2.3, 2.7 and $2.9 \mathrm{~mm}$ in bone gain for ridge, middle and apical area, respectively.

KEY WORDS: Bone regeneration; Maxilla; Dental implant; Bone defect; Biomaterials.

\section{INTRODUCTION}

One of the main challenges currently in the implantology field, is the development of more predictable procedures, regardless of the complexity of the clinical case. In this sense, one of the most important problems following tooth loss is the bone resorption process and collapse of the jaws through time. Alveolar resorption is a chronic, accumulative, irreversible and progressive disease (Fuentes et al., 2012), leading to esthetic and functional problems for implant installation (Wu et al., 2008).

Augmentation procedures require complex planning, high cost and sometimes a multi-step long lasting therapy. Extended treatment periods may be necessary to reach the final aesthetic outcome, depending on the technique and the type of graft used for maxillary or mandibular bone healing (Beltrán et al., 2013). Thus, several studies in animals and humans have attempted guided bone regeneration, and surgical techniques have been proposed with debatable results. As an alternative to the increase of bone volume, the use of a subperiosteal barrier and clot to allow development of bone tissue has been discussed. This technique provides a space that allows migration of osteogenic and angiogenic cells to the wound, stabilizing the bone grafts and blot clot (Ozdemir et al., 2013). Authors as Ludgren et al., (1998) reported that the best way to allow guided bone augmentation is with the use of stiff occlusive titanium barriers. These devices have been used in transverse maxillary bone defects with good results, depending on the barrier size and time placed in the donor bone or with association of biomaterials (Van Steenberghe et al., 2003; Engelke et al., 2004; Beltrán et al.).

Some researchers in guided bone regeneration, use titanium barriers to perform an alveolar ridge reconstruction

\footnotetext{
CIMOFIR Research Center, Facultad de Odontología, Universidad de La Frontera, Temuco, Chile.

** Dentistry Centre, Department of Oral and Maxillofacial Surgery, University of Göttingen, Göttingen, Germany.

**** Laboratorio de Bioimplantes, Facultad de Bioingenieria, Universidad Nacional de Entre Ríos, Entre Ríos, Argentina.

***** Departamento de Pediatría, Facultad de Medicina, Universidad de La Frontera, Temuco, Chile.

******* Facultad de Odontología, Universidad de Concepción, Concepción, Chile.

******* Ribeirão Preto Dental School, University of São Paulo, Ribeirão Preto, SP, Brazil.
} 
prior to implant placement (Rakhmatia et al., 2013), however the use of other manufacture material to produce this type of barrier had not been noted. Thus, the aim of this study was to show a minimally invasive surgical technique combined with the use of completely occlusive metallic barriers filled with allograft to achieve bone healing in width of maxillary transverse defects.

\section{MATERIAL AND METHOD}

The study was performed under the project research and development $\mathrm{N}^{\circ} 6081$ approved by the higher committee by resolution 027/05 of National University of Entre Rios, Argentina. Five patients (4 females and 1 male, aged 20 to 37 years), surgical procedure was explained to patients and informed consent was used for each surgery. Metallic barriers $4 \mathrm{~mm}$ in height, $4,5 \mathrm{~mm}$ in diameter, infraosseous border of $2.5 \mathrm{~mm}$ and beveled point were manufactured (FremiqSur ${ }^{\circledR}$, Temuco, Chile) and adequately sterilized under researchers supervision. In all cases the barriers were placed in the maxillary premolar region, with cortico-cancellous particulate allograft inside (Puros®, Zimmer Dental Inc., Carlsbad, CA, USA). Exclusion criteria were capsule motion or patient discomfort; in both cases, the barrier was immediately removed.

Surgical technique. An incision was carried out through alveolar ridge slightly larger than the defect area. Subsequently, a mucoperiosteal flap was realized. On approach and direct observation of the surgical region, the barrier location was determined. Prior to barrier installation a sterilized acrylic surgical guide was used to measure the distance in relation to cortical bone defect (Fig. 1). In all cases, the barrier was placed in the defect central area slightly higher than alveolar ridge (Fig. 2A), considering that the upper portion of barrier must be apical to maxillary sinus floor.

The next step was a cleft osteotomy in the barrier placement region through a standardized surgical trephine compatible with barrier size and shape. Subsequently, small perforations were realized with diamond burs in the internal zone of defect cleft, inserting the allograft inside the barrier and the same placed in the prepared area, carefully stabilized and fixed with surgical chisel and hammer. The barrier fixation and stabilization were checked through a surgical clamp.

The final step is the flap closure, situation in which the surgeon needs to previously check the passive closure. Sometimes, it was necessary to perform an augment of buccal mucoperiosteal flap or the indication of a free gingival graft, considering the size of area and the fibromucosa type. The suture was performed with Polyglactin 910 (Fig. 2B) (Vicryl®, Ethicon Endo-Surgery Inc., Greensboro, NC, USA) and controls realized after 1, 7, 30, 60, 90 days and 6 months (Fig. 3A). After this, the barrier site was checked though panoramic radiograph. Barriers removal was performed after 6 months of insertion (Fig. 3B) and the same sterilized acrylic surgical guide was used to measure the

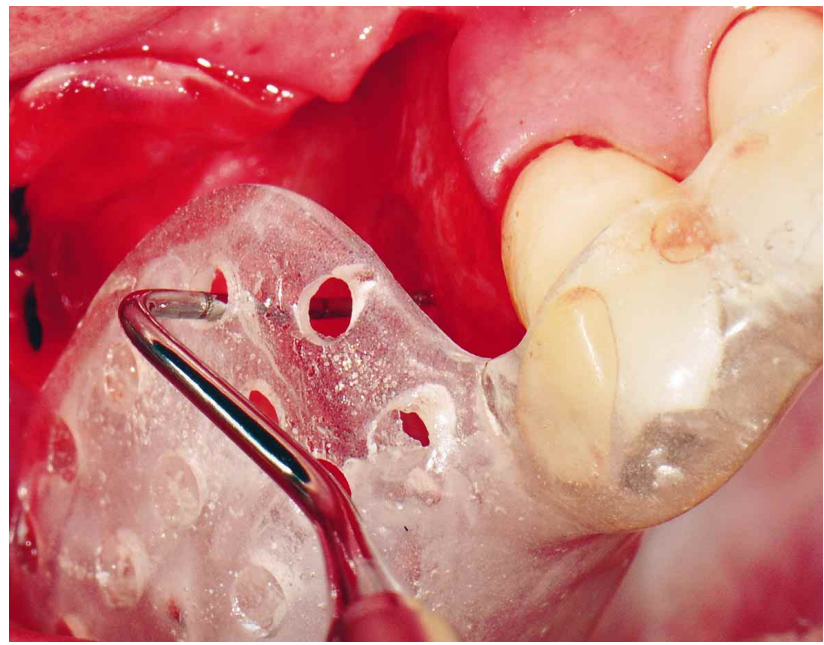

Fig. 1. Initial measurement of the distance to cortical bone with the help of acrylic surgical guide and periodontal probe.

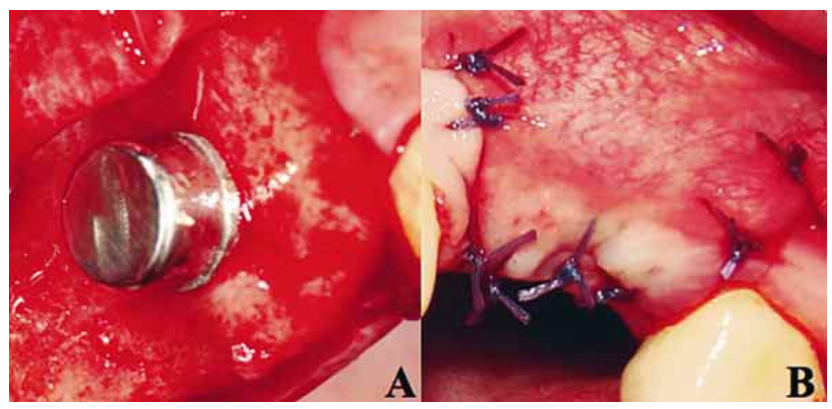

Fig. 2. A. Barrier in position over premolar region and apical to maxillary sinus floor; B. Mucoperiosteal flap sutured with the barrier in place.

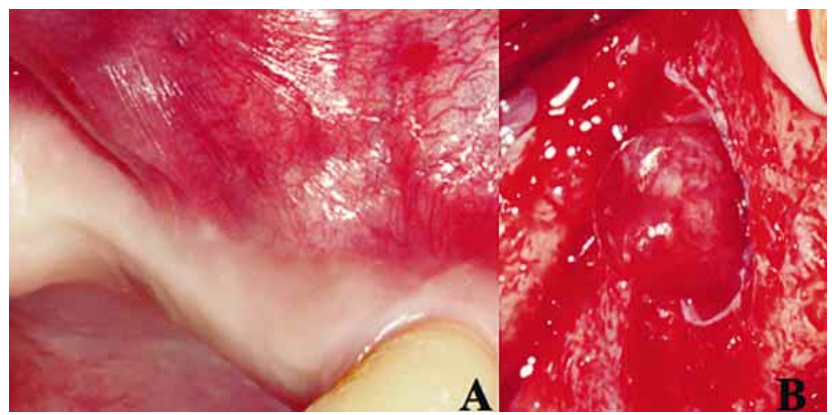

Fig. 3. A. Fibromucosa control at 6 months prior to barrier removal, not observing fenestration problems; B. Barrier removal showing the bone augmentation in width. 
distance of the cortical bone and compared with initial measurement. Also, a bone sample was obtained of each case, for histological analysis through Hematoxilin-Eosin and Masson Trichrome-Alcian Blue staining. Finally, we proceeded to immediately implant placement in the newly formed bone areas.

\section{RESULTS}

The bone augmentation in maxillary transverse defects with allograft inside the barrier may be observed in Table 1, identifying a mean of 2.3, 2.7 and $2.9 \mathrm{~mm}$ in bone gain for ridge, middle and apical area, respectively.

The histological analysis with both techniques showed the same findings: small amounts of newly formed bone with a predominance of collagen fibrous tissue and mature bone with very little cellular elements (Fig. 4A and 4B).

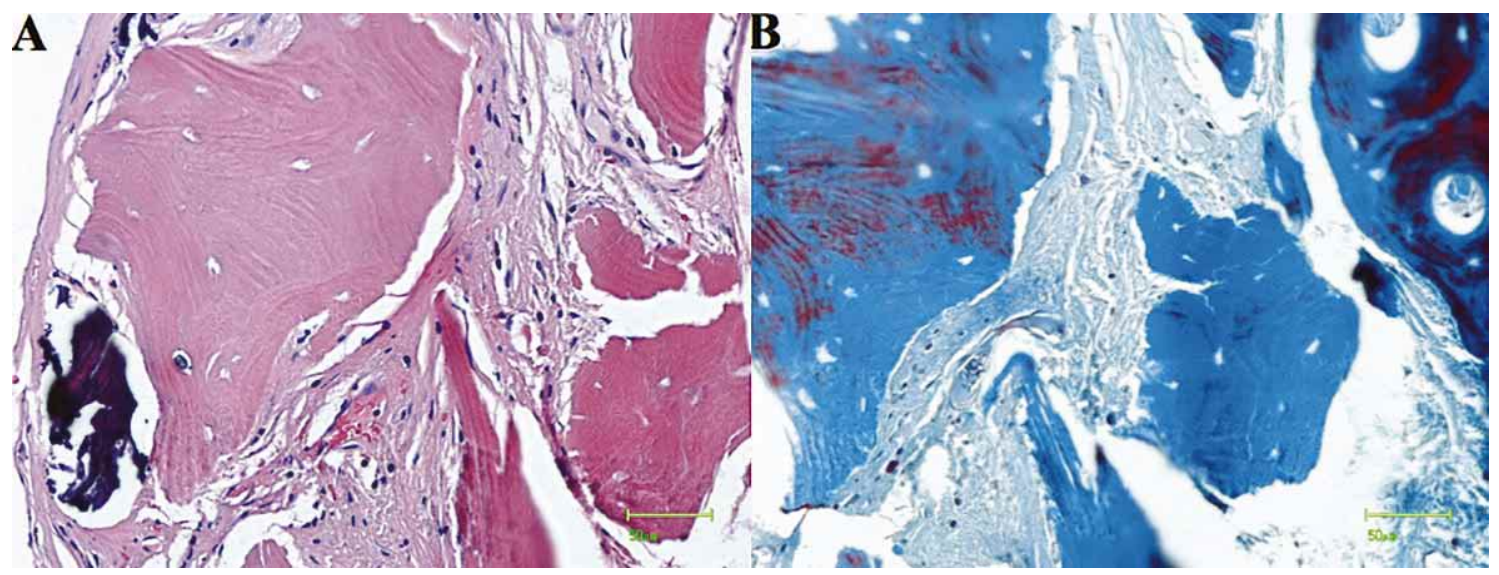

Fig. 4. Histological sample observing small amounts of newly formed bone with a predominance of collagen fibrous tissue in the middle and mature bone. A. Hematoxilin-Eosin staining, 200x; B. Masson Trichrome-Alcian Blue, 200x.

Table I.- Bone augmentation (B.A.) of the five cases in different measurement areas.

\begin{tabular}{llccc}
\hline Patients & Sex & $\begin{array}{c}\text { B.A. ridge area } \\
(\mathrm{mm})\end{array}$ & $\begin{array}{c}\text { B.A. middle area } \\
(\mathrm{mm})\end{array}$ & $\begin{array}{c}\text { B.A. apical area } \\
(\mathrm{mm})\end{array}$ \\
\hline Case 1 & Female & $+1.5 \mathrm{~mm}$ & $+2 \mathrm{~mm}$ & $+2 \mathrm{~mm}$ \\
Case 2 & Female & $+2 \mathrm{~mm}$ & $+3 \mathrm{~mm}$ & $+3 \mathrm{~mm}$ \\
Case 3 & Female & $+3 \mathrm{~mm}$ & $+3 \mathrm{~mm}$ & $+3,5 \mathrm{~mm}$ \\
Case 4 & Female & $+2,5 \mathrm{~mm}$ & $+3 \mathrm{~mm}$ & $+3 \mathrm{~mm}$ \\
Case 5 & Male & $+3 \mathrm{~mm}$ & $+3 \mathrm{~mm}$ & $+3 \mathrm{~mm}$ \\
\hline
\end{tabular}

\section{DISCUSSION}

Nowadays, one of implant placement limitations is the insufficient bone width to achieve implant stability which could be improved with certain surgical treatments clearly reported in the literature. For horizontal ridge augmentation, clinical evidence favors intraoral autogenous bone, however the morbidity of the donor site and post-surgical problems may be avoided through allografts (Mihatovic et al., 2012). Allografts are biomaterials that belong to individuals genetically different but of the same species (Martínez et al., 2011). Thus, allografts and bone substitutes in combination with guided bone regeneration are associated with a clinically important horizontal bone gain for lateral ridge augmentation (Strietzel et al., 2007; Hämmerle et al., 2008). Guided bone augmentation seems to be a good alternative to increased bone quantity, in which a subperiosteal barrier is placed allowing the underlying blood clot to mineralize (Molly et al., 2006). This 
technique can be enhanced by inserting some material underneath (Buser et al., 1996; Nevins et al., 1998). The best way to allow bone neogenesis is the use of a stiff occlusive titanium membrane. However, we noted that the metallic barrier designed in this study exhibited good results with considerable bone width augmentation in all cases and with a range of 2.3-2.9 mm of bone gain.

A technique with occlusive barriers may influence augmentative procedures in various alveolar sites because the concept is based on performing well-known surgical principles using a flapless approach and a secure spacemaking device to achieve guided bone regeneration (Engelke et al.). The main advantage of the use of this technique with a rigid barrier is that surgery may be suitable with local anesthesia when compared to aggressive autologous bone grafts surgeries to obtain bone blocks of hip (Van Steenberghe et al.).

Although the histological findings showed a considerable quantity of collagen fibers, differing of ideal bone regeneration processes, the fact that the sample presented very few cellular elements, did not mean that in this state of quiescence (metabolically inactive) (Fuentes et al., 2011). The persistence of fibrillar tissue was observed in different amounts following six months after biomaterial application. Although, no remaining intact biomaterial was observed in any of the biopsies, concurring with the findings of Fuentes et al. (2011), who test a similar biomaterial (freeze-dried bone allograft) in alveolar sockets. Furthermore, preservation of fibrous tissue areas for more than 4 weeks in a situation observed by other researchers using biomaterials (Lee et al., 2008).

Furthermore, some factors have been shown to be critical for a successful outcome during the surgery such as barrier stability, size of barrier perforations, peripheral sealing between the barrier and bone, blood supply, and access to bone-forming cells, among others (Lundgren et al., 1995; Slotte \& Lundgren, 1999; Tamura et al., 2005).

\section{CONCLUSION}

This technique was considered reliable and surgically minimally invasive for transverse maxillary bone defects of medium and high complexity. Post-surgical consequences in relation to inflammation, bleeding and complications were minimal in other dental or neurovascular structures, without the need of donor site or surgical screws.

BELTRÁN, V.; ENGELKE, W.; FUENTES, R.; DECCO, O.; PRIETO, R.; WILCKENS, M. \& BORIE, E. Aumento óseo con barreras oclusivas y aloinjerto cortical particulado en defectos maxilares transversales: un estudio piloto. Int. J. Morphol., 32(1):364$368,2014$.

RESUMEN: La reabsorción centrípeta del maxilar es un proceso continuo después de la pérdida dentaria. Para el tratamiento de sitios óseos deficientes, se pueden utilizar injertos de hueso autólogo; como alternativa, se puede aplicar biomateriales, que no requieren sitios donantes intra o extraorales. El presente reporte describe la utilización de barreras oclusivas y aloinjerto cortical particulado en defectos maxilares transversales. Este abordaje quirúrgico fue realizado en cinco pacientes (4 mujeres y 1 hombre, de 20 hasta 37 años de edad). Los resultados clínicos muestran que se formó suficiente tejido duro para permitir la rehabilitación de implantes en los sitios de hueso insuficiente. La evaluación histológica reveló pequeñas cantidades de hueso neoformado con predominantes fibras colágenas y hueso maduro con muy pocos elementos celulares. Dependiendo de la situación del sitio original, se puede aplicar un abordaje mínimamente invasivo con barreras oclusivas y aloinjerto cortical particulado. Se pudo observar un aumento óseo promedio de 2,3, 2,7 y 2,9 mm para las regiones de la cresta ósea, zona media y apical, respectivamente.

PALABRAS CLAVE: Regeneración ósea; Maxilar; Implante dental; Defectos óseos; Biomateriales.

\section{REFERENCES}

Beltrán, V.; Matthijs, A.; Borie, E.; Fuentes, R.; Valdivia-Gandur, I. \& Engelke, W. Bone healing in transverse maxillary defects with different therapies with anorganic bovine bone in humans. Int. J. Morphol., 31(1):75-81, 2013.

Buser, D.; Dula, K.; Lang, N. P. \& Nyman, S. Long-term stability of osseointegrated implants in bone regenerated with the membrane technique. 5-year results of a prospective study with 12 implants. Clin. Oral Implants Res., 7(2):175-83, 1996.
Engelke, W.; Decco, O. \& Rau, M. J. Minimal invasive augmentation des Unterkiefer mit einem mikrofixierten starren Formkörper. ZWR, 113:399-402, 2004.

Fuentes, R.; Issa, J. P. M.; Iyomasa, M. M.; Oporto, G.; Prieto, R. $\&$ Borie, E. The behavior of demineralized bone matrix (DB;) in post-extraction sockets. Int. J. Morphol., 30(2):394-8, 2012.

Fuentes, R.; Oporto, V. G.; Olate, S.; Rojas, R. M.; Borie, E. \& 
Engelke, W. Histological evaluation of bone regeneration means freeze dried bone allograft (FDBA) in post exodontia sockets. Int. J. Morphol., 29(1):286-92, 2011.

Hämmerle, C. H.; Jung, R. E.; Yaman, D. \& Lang, N. P. Ridge augmentation by applying bioresorbable membranes and deproteinized bovine bone mineral: a report of twelve consecutive cases. Clin. Oral Implants Res., 19(1):19-25, 2008.

Lee, J. H.; Jung, U. W.; Kim, C. S.; Choi, S. H. \& Cho, K. S. Histologic and clinical evaluation for maxillary sinus augmentation using macroporous biphasic calcium phosphate in human. Clin. Oral Implants Res., 19(8):767-71, 2008.

Lundgren, A.; Lundgren, D. \& Taylor, A. Influence of barrier occlusiveness on guided bone augmentation. An experimental study in the rat. Clin. Oral Implants Res., 9(4):251-60, 1998.

Lundgren, D.; Lundgren, A. K.; Sennerby, L. \& Nyman, S. Augmentation of intramembraneous bone beyond the skeletal envelope using an occlusive titanium barrier. An experimental study in the rabbit. Clin. Oral Implants Res., 6(2):67-72, 1995.

Martínez, G.; Llamosa, L.; Beltrán, V.; Cantín, M. \& Fuentes, R. Terapia periodontal mediante proteínas derivadas de la matriz del esmalte y aloinjerto óseo. Int. J. Odontostomat., 5:279-86, 2011.

Mihatovic, I.; Becker, J.; Golubovic, V.; Hegewald, A. \& Schwarz, F. Influence of two barrier membrane on staged guided bone regeneration and osseointegration of titanium implants in dogs. Part 2: augmentation using bone graft substitutes. Clin. Oral Implants Res., 23(3):308-15, 2012.

Molly, L.; Quirynen, M.; Michiels K. \& Van Steenberghe, D. Comparison between jaw bone augmentation by means of a stiff occlusive titanium membrane or an autologous hip graft: a retrospective clinical assessment. Clin. Oral Implants Res., 17(5):481-7, 2006.

Nevins, M.; Mellonig, J. T.; Clem, D. S. 3rd.; Reiser, G. M. \& Buser, D. A. Implants in regenerated bone: long-term survival. Int. J. Periodontics Restorative Dent., 18(1):34-45, 1998.

Ozdemir, H.; Ezirganli, S.; Isa Kara, M.; Mihmanli, A. \& Baris, E. Effects of platelet rich fibrin alone used with rigid titanium barrier. Arch. Oral Biol., 58(5):537-44, 2013.

Rakhmatia, Y. D.; Ayukawa, Y.; Furuhashi, A. \& Koyano, K. Current barrier membranes: titanium mesh and other membranes for guided bone regeneration in dental applications. J. Prosthodont. Res., 57(1):3-14, 2013.

Slotte, C. \& Lundgren, D. Augmentation of calvarial tissue using non-permeable silicone domes and bovine bone mineral. An experimental study in the rat. Clin. Oral Implants Res., 10(6):468-76, 1999.
Strietzel, F. P.; Reichart, P. A. \& Graf, H. L. Lateral alveolar ridge augmentation using a synthetic nano-crystalline hydroxyapatite bone substitution material (Ostim): preliminary clinical and histological results. Clin. Oral Implants Res., 18(6):743-51, 2007.

Tamura, T.; Fukase, Y.; Goke, E.; Yamada, Y.; Sato, S.; Nishiyama, M. \& Ito, K. Three-dimensional evaluation for augmented bone using guided bone regeneration. J. Periodontal Res., 40(3):26976, 2005.

Van Steenberghe, D.; Johansson, C.; Quirynen, M.; Molly, L.; Albrektsson, T. \& Naert, I. Bone augmentation by means of a stiff occlusive titanium barrier. Clin. Oral Implants Res., 14(1):63-71, 2003.

Wu, Z.; Liu, C.; Zang, G. \& Sun, H. The effect of simvastatin on remodelling of the alveolar bone following tooth extraction. Int. J. Oral Maxillofac. Surg., 37(2):170-6, 2008.

Correspondence to:

Víctor Beltrán Varas

Faculty of Dentistry

Universidad de La Frontera

Claro Solar N. 115 - Of. 420, Temuco

CHILE

Email: victor.beltran@ufrontera.cl

Received: 28-10-2013

Accepted: 04-01-2014 